\title{
4 \\ KONSTRUKSI LANGEN TAYUB NGANJUK DALAM PERSPEKTIF BERGERIAN
}

ANIK JUWARIYAH

\begin{abstract}
Internalization's phase of society as a subjective fact implies that the objective reality interpreted subjectively by the individual. In a process of interpreting that internalization took place. Internalization is the process experienced by humans to 'take over' the world that are inhabited neighbor. Internalization lasts a lifetime involving socialization, both primary and secondary. Developing knowledge in agrarian societies instituted in continuous tradition and heredity. In theory of Berger and Luckmann, this sort of thing is to be part of a social construction, in particular objectivation stage. For Berger, is a product of human society, rooted in externaliation phenomenon. Langen tayub is seen as a knowledge that is maintained and applied through tradition and process interactions that exist in society.
\end{abstract}

Keywords: Langen Tayub construction, Nganjuk, Bergerian.

\section{PENDAHULUAN}

Kesenian Langen Tayub sebagai kesenian tradisional agraris telah memiliki akar tradisi yang kuat dalam kehidupan masyarakat Kabupaten Nganjuk. Seni Langen Tayub atau Langen Beksa pada sebagian besar wilayah Nganjuk selama ini dapat dikatakan mampu bertahan hidup dalam perubahan sosial budaya yang ada, meskipun dalam beberapa hal telah mengalami pergeseran. Para pelaku seniman Langen Tayub terdiri atas waranggana (penari Tayub), pramugari Tayub (orang yang mengatur jalannya pentas Langen Tayub), penayub (penari Langen Tayub laki-laki yang menari dengan waranggana) dan pengrawit (pengiring atau penabuh karawitan).

Berger dalam Susilo (2008: 329) menyatakan bahwa setiap masyarakat memiliki sistem pengetahuan yang diterima secara turun temurun. Gagasan pengetahuan yang bersifat lokal (beberapa kalangan mengatakan sebagai tradisional) hampir ada pada setiap masyarakat, termasuk dalam masyarakat agraris.

Dalam masyarakat agraris dikenal beberapa jenis pengetahuan yang bisa dikatakan sebagai mitos, takhayul, pamali,prewangan, atau apapun namanya, tetapi yang jelas masyarakat yang menciptakan, mengembangkan, dan memodifikasi. Konon, seorang kakek menyarankan pada cucunya agar selalu mengadakan kenduri di hari-hari tertentu yang diyakini keramat.Ia percaya pada suatu cerita dari leluhur, yakni suatu malam pernah ada orang ditampar makhluk yang tidak kelihatan gara-gara tidak mengadakan kenduri. Sejak saat itu bagi sebagian masyarakat kenduri atau selamatan menjadi sistem adat yang diterima begitu saja dan sulit ditinggalkan.

Pada masyarakat Nganjuk pengetahuan semacam ini sudah berlangsung turun temurun. Pengetahuan yang sudah menjelma menjadi sistem adat ini masih berkembang dan mewarnai kehidupan masyarakat.Kenduri atau selamatan untuk memulai awal perhelatan sebuah perkawinan, kenduri untuk memulai menanam padi, kenduri untuk bersih desa, dan lain-lain. Pengetahuan ini lebih lanjut terkait dengan bentuk kesenian yang harus dihadirkan dalam sebuah perhelatan. Kesenian Langen Tayub, Wayang Kulit, Jaranan, Wayang Krucil adalah beberapa bentuk kesenian tradisional yang men- 
giringi perhelatan-perhelatan di masyarakat untuk kepentingan penyelenggaraan sistem adat.

Pengaruh budaya yang kuat serta kondisi lingkungan masyarakat agraris yang mendukung dalam menyelenggarakan kehidupannya, menyebabkan masyarakat sangat mentaati adat budaya yang telah turun temurun diyakini oleh masyarakat pedesaaan khususnya dan masyarakat Nganjuk umumnya, seperti contohnya dalam menyelenggarakan hajat perkawinan.

\section{PROSES INTERNALISASI DALAM MASYARAKAT AGRARIS}

Tahap internalisasi masyarakat sebagai kenyataan subyektif menyiratkan bahwa realitas obyektif ditafsiri secara subyektif oleh individu. Dalam proses menafsiri itulah berlangsung internalisasi. Internalisasi adalah proses yang dialami manusia untuk 'mengambil alih' dunia yang sedang dihuni sesamanya. Internalisasi berlangsung seumur hidup melibatkan sosialisasi, baik primer maupun sekunder. Internalisasi adalah proses penerimaan definisi situasi yang disampaikan orang lain tentang dunia institusional. Dengan diterimanya definisi-definisi tersebut, individu pun bahkan tidak hanya mampu memahami definisi orang lain, tetapi lebih dari itu, turut mengkonstruksi definisi bersama. Dalam proses mengkonstruksi inilah, individu berperan aktif sebagai pembentuk, pemelihara, sekaligus perubah masyarakat.

BERGER dan LuCKMANN (1990: 87) menyatakan bahwa dalam internalisasi, individu mengidentifikasikan diri dengan berbagai lembaga sosial atau organisasi sosial dimana individu menjadi anggotanya. Internalisasi merupakan peresapan kembali realitas oleh manusia dalam hal ini para pelaku Langen Tayub di Kabupaten Nganjuk dan mentransformasikan kembali dari struktur-struktur dunia objektif ke dalam struktur-struktur kesadaran subjektif. Dikatakan BERGER dan LUCKMAN setelah mencapai taraf internalisasi inilah individu menjadi anggota masyarakat. Proses untuk mencapai taraf itu dilakukan dengan sosialisasi (1990: 186).
Di acara bersih desa, berkumpullah warga desa bukan hanya yang tinggal di wilayah tersebut saja, tapi juga warga masyarakat yang tinggalnya di rantau. BLUMER dalam Poloma (2000: 259-260) menyatakan :

Aktor memilih, memeriksa, berpikir, mengelompokkan dan mentransformasikan makna dalam hubungannya dengan situasi dimana dia ditempatkan dan arah tindakannya. Sebenarnya, interpretasi seharusnya tidak dianggap hanya sebagai penerapan makna-makna yang telah ditetapkan, tetapi sebagai suatu proses pembentukan dimana makna yang dipakai dan disempurnakan sebagai instrumen bagi pengarahan dan pembentukan tindakan.

\section{OBJEKTIVASI LANGEN TAYUB DALAM MASYARAKAT AGRARIS}

Dalam tahap objektivasi masyarakat sebagai realitas obyektif menyiratkan pelembagaan di dalamnya. Proses pelembagaan (institusionalisasi) diawali oleh eksternalisasi yang dilakukan berulang-ulang sehingga terlihat polanya dan dipahami bersama yang kemudian menghasilkan pembiasaan (habitualisasi). Habitualisasi yang telah berlangsung memunculkan pengendapan dan tradisi. Pengendapan dan tradisi ini kemudian diwariskan ke generasi sesudahnya melalui bahasa. Disinilah terdapat peranan di dalam tatanan kelembagaan, termasuk dalam kaitannya dengan pentradisian pengalaman dan pewarisan pengalaman tersebut. Jadi, peranan mempresentasikan tatanan kelembagaan atau lebih jelasnya; pelaksanaan peranan adalah representasi diri sendiri. Peranan mempresentasikan suatu keseluruhan rangkaian perilaku yang melembaga, misalnya peranan hakim dengan peran-peran lainnya di sektor hukum.

Masyarakat sebagai realitas obyektif juga menyiratkan keterlibatan legitimasi. Legitimasi merupakan obyektivasi makna tingkat kedua, dan merupakan pengetahuan yang berdimensi kognitif dan normatif karena tidak hanya menyangkut penjelasan tetapi juga nilai-nilai. Legitimasi berfungsi untuk membuat obyektivasi yang sudah 
melembaga menjadi masuk akal secara subyektif.

Pengetahuan yang berkembang dalam masyarakat agraris dilembagakan dalam tradisi yang terus menerus dan turun temurun. Dalam teorinya Berger dan Luckmann hal semacam ini menjadi bagian dari sebuah konstruksi sosial, khususnya tahap objektivasi.Bagi Berger masyarakat adalah produk manusia, berakar pada fenomena ekternalisasi. Produk manusia (termasuk dunianya sendiri), kemudian berada di luar dirinya, menghadapkan produk-produk sebagai aktivitas yang ada di luar dirinya. Meskipun semua produk kebudayaan itu berasal dari kesadaran manusia, namun produk bukan serta merta dapat diserap kembali begitu saja ke dalam kesadaran, sebagaimana halnya yang terjadi juga pada pelaku Langen Tayub.

Kebudayaan berada di luar subjektivitas manusia, menjadi dunianya sendiri.Dunia yang diproduksi manusia memperoleh sifat realitas objektif (BERGER, 1994: 11-12). Semua aktivitas manusia yang terjadi dalam eksternalisasi, menurut BERGER dan LUCKMANN (1990: 75-76), dapat mengalami proses pembiasaan (habitualisasi) yang kemudian mengalami kelembagaan (institusialisasi).

Langen Tayub dipandang sebagai sebuah pengetahuan yang terus dipelihara melalui tradisi dalam proses interaksi yang ada di masyarakat. Dalam aktivitas Langen Tayub masyarakat saling berinteraksi dan berkomunikasi untuk melembagakan pengetahuan mereka agar tetap terpelihara dengan baik.Sebagaimana pernyataan Berger dan LuCKMANN (2009: 38), "Sosiologi pengetahuan seharusnya mengkaji segala dimensi pengetahuan dalam masyarakat, termasuk seperti pengetahuan awam, atau pengetahuan sehari-hari". Pengetahuan tentang keharusan menyajikan Langen Tayub untuk acara bersih desa telah menjadi pengetahuan sehari-hari di masyarakat dan diyakini serta dilakukan secara terus menerus dan menjadi tradisi masyarakat, sebagaimana pernyataan Sudarmadji:

"Langen Tayub diselenggarakan di setiap acara nyadran memang sudah menjadi adat dan turun temurun. Nyadran dilakukan di punden yang berupa pohon besar pada setiap hari Jumat Pahing bulan Suro (tahun Jawa), setelah panen. Jika nyadran tidak menyelenggarakan Tayuban dan bulannya bukan bulan Suro maka akan terjadi hal-hal yang tidak diinginkan. Pernah terjadi kecelakan dalam setahun sebanyak 26 kali kecelakaan menimpa warga desa Kepanjen, termasuk saya sendiri”.

BERger dan LuCKMANN menggagas perubahan pada dua hal dalam sosiologi pengetahuan.Pertama, Berger berusaha mengubah persepsi bahwa sosiologi pengetahuan merupakan disiplin yang hanya mengkaji sejarah perkembangan sebuah gagasan atau ideologi.Berger melihat bahwa selama ini, sosiologi pengetahuan cenderung lebih berorientasi mengkaji sejarah munculnya suatu gagasan atau ide-ide intelektual.Kedua, BERGER menetapkan bahwa sosiologi pengetahuan merupakan ilmu yang mempelajari hubungan antara konteks sosial dan pengetahuan manusia. BERGER menekankan hubungan antara manusia dan pengetahuan serta realitasnya adalah hubungan yang sifatnya resiprokal atau timbal balik. Manusia hidup bersama dan membentuk masyarakat sebagai sebuah pengetahuan, dan pengetahuan sebagai realitas yang balik membentuk manusia (RIYANTO, 2009: 38).

Pengetahuan masyarakat yang sudah turun temurun dilembagakan dalam berbagai bentuk tradisi atau sistem adat di masyarakat agraris. Masyarakat Nganjuk yang mayoritas mata pencahariannya sebagai petani dan hidup dalam masyarakat agraris masih memelihara bentuk-bentuk pengetahuan dari nenek moyang. Langen Tayub sebagai sebuah realitas kultural dan realitas sosial membentuk manusia sebagai bagian dari masyarakat yang mempunyai sistem adat yang sudah turun temurun dan mentradisi.

Berdasarkan temuan data di lapangan, ada beberapa perubahan-perubahan dan hal itu mempengaruhi bagan konsep sosiologinya Berger dan Luckmann. Apabila konsep ini diterapkan pada kajian penelitian ini, maka akan terlihat sebagaimana gambar berikut. 


\begin{tabular}{|l|}
\hline Langen Tayub Nganjuk sekarang \\
\hline 1. - perubahan tradisi \\
2. - pengaruh ajaran Islam \\
3. - modernisasi \\
4. - Langen Tayub Padang Bulan \\
5. - Perubahan fungsi \\
\hline Langen Tayub lama \\
\hline $\begin{array}{l}\text { Ada nilai-nilai Jawa, Hindu, Sinkretik, dan } \\
\text { adaptasi }\end{array}$ \\
\hline
\end{tabular}

Bagan. Langen Tayub dalam Posisinya Sebagai Pengetahuan di Masyarakat Agraris Menurut Konsep Sosiologi Pengetahuan Peter L. Berger dan LUCKMANN.

\section{Eksternalisasi dalam Konstruksi Realitas Sosial Langen Tayub Nganjuk}

Sesuai tahap eksternalisasi BERGER dan LuCKMANN, individu khususnya para seniman Langen Tayub mencurahkan segala pikiran, tenaga dan waktunya sebagaimana konsep eksternalisasinya Peter Berger dan Luckmann, yang menyatakan bahwa "Tatanan sosial itu bermula dari eksternalisasi, yakni: pencurahan kedirian manusia secara terus menerus ke dalam dunia, baik dalam aktivitas fisik maupun mentalnya(BERGER, 1991:4-5). Individu seniman Tayub sebagai anggota komunitas penggemar Langen Tayub dan sebagai anggota masyarakat melakukan aktivitas fisik yang berhubungan dengan pagelaran Langen Tayub, menghadiri pertunjukan yang dilakukan di berbagai tempat meskipun jauh dari tempat tinggalnya,menampilkan pertunjukan Langen Tayub, melakukan komunikasi dengan dinas terkait, dalam hal ini Dinas pariwisata dan Kebudayaan Daerah Kabupaten Nganjuk, melakukan pelatihan dan pengembangan kemampuan berkesenian.

Dalam pementasan Langen Tayub, seorang individu seniman akan muncul sesuai dengan konsep yang telah menjadi kesepakatan yang tumbuh dalam komunitas Langen Tayub. Di atas panggung, seorang penayub yang berinteraksi dengan waranggana maupun sesama penayub akan memerankan dirinya secara total sesuai karakter masing-masing. Karakter yang muncul dari beberapa individu itulah yang nantinya membentuk identitas seniman Langen Tayub, yang dalam masyarakat biasa atau masyarakat bukan penggemar Langen Tayub dianggap sebagai tindakan yang kurang sopan atau kurang etis. Demikian juga dengan peran pramugari Tayub, di atas panggung dia harus dapat memerankan sebagai orang yang harus dapat fleksibel berhubungan dengan waranggana, penayub, dan yang mempunyai hajat, contohnya pramugari Tayub yang bernama DAMIRAN. Berdasarkan pengamatan terhadap pementasan DAMIRAN sebagai salah satu pramugari Tayub yang sedang laris di Nganjuk gerakan lucu yang sering dilakukan pramugari Tayub yang bernama DAMIRAN, antara lain seperti gerakan bagong, gareng, jaranan, gerakan tari Remo, dan lain-lain. Gerakan itu sengaja ditampilkan untuk menyemarakkan suasana.Kenyataannya para seniman Langen Tayub dan masyarakat yang mempunyai hajat sangat menggemari tindakan ini. Hal itu terbukti semakin lama DAMIRAN semakin penuh jadwal pementasannya. Disamping sebenarnya karena kemampuannya yang lain seperti: keramah-tamahan, kemampuan olah gerak, penguasannnya terhadap gendhing-gendhing yang ada, dan kemampuannya berinteraksi dan komunikasi dengan berbagai lapisan masyarakat dari rakyat biasa sampai pejabat pemerintahan. Dalam posisinya sebagai pengatur jalannya pentas Langen Tayub, Damiran berhak mengatur siapa urutan tamu yang menari bersama waranggana. Dia berkuasa penuh juga mengatur pasangan menari antara waranggana dengan penayub. Dalam kasus ini DAMIRAN dapat dikatakan sebagai individu yang mempunyai identitas yang jelas, yang diakui masyarakatnya, sesuai dengan pendapat BERGER dan LUCKMANN.

Identitas merupakan satu unsur kunci kenyataan subyektif dan berhubungan secara dialektis dengan masyarakat.Identitas dibentuk oleh proses-proses sosial. Begitu ia memperoleh wujudnya, ia dipelihara, dimodifikasi, atau mala- 
han dibentuk ulang oleh hubungan-hubungan sosial. Proses-proses sosial yang terlibat dalam membentuk dan mempertahankan identitas ditentukan oleh struktur sosial. Masyarakat mempunyai sejarah dan di dalam perjalanan sejarah itu muncul identitas-identitas khusus; tetapi sejarah-sejarah itu dibuat oleh manusia dengan identitas-identitas tertentu (1990: 248).

Tampaknya DAmIRAN sudah berhasil melakukan sebuah internalisasi yang baik dari apa yang sudah didapat selama ini melalui pengalaman-pengalaman mengikuti berbagai kegiatan pementasan Langen Tayub di berbagai daerah dan sering menjadi wakil Kabupaten Nganjuk dalam festival-festival maupun pagelaran Langen Tayub di Taman Mini Indonesia Indah (Jakarta). Hasil dari internalisasi yang dia lakukan, tampak dari ekternalisasinya yang menunjukkan sebuah sajian menarik. Hal itu dilakukan secara terus menerus dalam setiap penampilannya (proses sosial), dan akhirnya dilegitimasi masyarakat.

Berdasarkan beberapa pengamatan terhadap pementasan Langen Tayub di Nganjuk dapat disajikan bentuk-bentuk eksternalisasi yang dilakukan para pelaku pementasan Langen Tayub di arena front stage, seperti tampak dalam tabel berikut.

Tabel 1. Tindakan Pelaku Langen Tayub di Arena Front Stage

\begin{tabular}{|c|l|l|l|}
\hline No & Pelaku & \multicolumn{1}{|c|}{ Tindakan } & Adegan/Tahap \\
\hline 1 & Penayup & $\begin{array}{l}\text { Memberi hormat ke } \\
\text { pasangan menari den- } \\
\text { gan menunjukkan ibu } \\
\text { jari sambil menunduk. }\end{array}$ & Tayuban \\
\cline { 2 - 4 } & $\begin{array}{l}\text { Menggoda temannya } \\
\text { yang sedang menari } \\
\text { dengan waranggana, } \\
\text { menarik-narik sampur } \\
\text { temannya. }\end{array}$ & Tayuban \\
\cline { 2 - 4 } & $\begin{array}{l}\text { Menari berputar-pu- } \\
\text { tar, menari dengan } \\
\text { gerakan yang bebas } \\
\text { sesuai kemampuannya } \\
\text { masing-masing }\end{array}$ & Ndara-ndara \\
\cline { 2 - 4 } & $\begin{array}{l}\text { Ikut nembang/men- } \\
\text { yanyi (bagi yang hafal } \\
\text { syair lagunya), yang } \\
\text { kurang hafal dibimbing } \\
\text { waranggana. Adaka- } \\
\text { lanya di tengah-tengah } \\
\text { menyanyikan tembang }\end{array}$ & Ndara-ndara \\
\hline
\end{tabular}

\begin{tabular}{|c|c|c|c|}
\hline No & Pelaku & Tindakan & Adegan/Tahap \\
\hline & & $\begin{array}{l}\text { mereka bersendau } \\
\text { gurau. }\end{array}$ & \\
\hline & & $\begin{array}{l}\text { Makan camilan sambil } \\
\text { geleng-geleng kepala } \\
\text { mengikuti alunan tem- } \\
\text { bang, minuman }\end{array}$ & Ndara-ndara \\
\hline & & $\begin{array}{l}\text { Ngobrol/bincang-bin- } \\
\text { cang akrab dengan } \\
\text { waranggana }\end{array}$ & Ndara-ndara \\
\hline & & $\begin{array}{l}\text { Menggoda temannya } \\
\text { yang sedang nembang, } \\
\text { sambil ikut nembang }\end{array}$ & Ndara-ndara \\
\hline & & $\begin{array}{l}\text { Merokok sambil } \\
\text { ngobrol dengan sesama } \\
\text { penayub }\end{array}$ & Ndara-ndara \\
\hline & & $\begin{array}{l}\text { Minum bir dan minu- } \\
\text { man yang lain secara } \\
\text { berulang-ulang sampai } \\
\text { beberapa gelas }\end{array}$ & Ndara-ndara \\
\hline & & $\begin{array}{l}\text { Menawarkan camilan ke } \\
\text { sesama penayub }\end{array}$ & Ndara-ndara \\
\hline & & $\begin{array}{l}\text { Berkeliaran di arena } \\
\text { sekitar panggung, } \\
\text { adakalanya ada yang } \\
\text { sampai mabuk }\end{array}$ & \\
\hline & & $\begin{array}{l}\text { Setengah mabuk } \\
\text { dengan menempelkan } \\
\text { badannya ke penayub } \\
\text { yang berada di sebe- } \\
\text { lahnya }\end{array}$ & Ndara-ndara \\
\hline & & $\begin{array}{l}\text { Bergerak sekedarnya } \\
\text { seperti molet }\end{array}$ & \\
\hline & & $\begin{array}{l}\text { Penayub yang sudah tua } \\
\text { adakalanya geraknya } \\
\text { sangat pelan dan me- } \\
\text { nolehkan kepalanya ke } \\
\text { kiri dan ke kanan. }\end{array}$ & \\
\hline & & $\begin{array}{l}\text { Di akhir tahapan } \\
\text { ngibing, penayub yang } \\
\text { selesai menari member- } \\
\text { ikan kembali sampur } \\
\text { yang dipakai kepada } \\
\text { waranggana. }\end{array}$ & \\
\hline \multirow[t]{4}{*}{2} & \multirow[t]{4}{*}{$\begin{array}{l}\text { Pramugari } \\
\text { Tayub }\end{array}$} & $\begin{array}{l}\text { Membuka acara dan } \\
\text { menyampaikan tata ter- } \\
\text { tib pementasan Langen } \\
\text { Tayub }\end{array}$ & \\
\hline & & $\begin{array}{l}\text { Gedog, yaitu menari } \\
\text { sendiri sambil membawa } \\
\text { baki yang ada sampur/ } \\
\text { selendang. }\end{array}$ & Gedog \\
\hline & & $\begin{array}{l}\text { Pesan gendhing ke } \\
\text { pengrawit }\end{array}$ & $\begin{array}{l}\text { Penghubung } \\
\text { antara } \\
\text { ndara-ndara } \\
\text { dan tayuban }\end{array}$ \\
\hline & & $\begin{array}{l}\text { Mendatangi kumpulan } \\
\text { penayub sambil men- } \\
\text { catat urutan penampilan } \\
\text { para penayub, dengan } \\
\text { sesekali duduk sebentar } \\
\text { diantara para penayub } \\
\text { sambil bersenda gurau }\end{array}$ & Ndara-ndara \\
\hline
\end{tabular}




\begin{tabular}{|c|c|c|c|}
\hline No & Pelaku & Tindakan & Adegan/Tahap \\
\hline & & $\begin{array}{l}\text { Mengatur urutan } \\
\text { penampilan penayub } \\
\text { yang menari bersama } \\
\text { waranggana }\end{array}$ & \\
\hline & & $\begin{array}{l}\text { Melantunkan sebagian } \\
\text { gendhing diantara per- } \\
\text { gantian antar penayub } \\
\text { yang menari dengan } \\
\text { waranggana }\end{array}$ & \\
\hline & & $\begin{array}{l}\text { Menyapa para tamu/ } \\
\text { penayub }\end{array}$ & \\
\hline & & $\begin{array}{l}\text { Melakukan gerakan-gera- } \\
\text { kan yang lucu/gecul. }\end{array}$ & \\
\hline & & $\begin{array}{l}\text { Berkomunikasi/ } \\
\text { bercakap-cakap dan } \\
\text { bersenda gurau dengan } \\
\text { waranggana }\end{array}$ & \\
\hline & & Minum bir & \\
\hline \multirow[t]{7}{*}{3} & \multirow[t]{7}{*}{ Waranggana } & $\begin{array}{l}\text { Nembang secara } \\
\text { individu, baik di tahap } \\
\text { ndara-ndara (dalam } \\
\text { posisi duduk) maupun } \\
\text { tayuban (menari dengan } \\
\text { penayub) }\end{array}$ & $\begin{array}{l}\text { Ndara-ndara } \\
\text { dan tayuban }\end{array}$ \\
\hline & & Menari Gambyong & Pembukaan \\
\hline & & $\begin{array}{l}\text { Menuangkan minuman } \\
\text { bir ke penayub dengan } \\
\text { gelas bekas minuman } \\
\text { kemasan }\end{array}$ & Ndara-ndara \\
\hline & & $\begin{array}{l}\text { Menari diatas pang- } \\
\text { gung dengan penayub } \\
\text { yang beraneka tipe dan } \\
\text { karakter. Terkadang } \\
\text { harus menari dan men- } \\
\text { yanyi sambil berkelakar } \\
\text { dengan penayub diatas } \\
\text { panggung. }\end{array}$ & Tayuban \\
\hline & & $\begin{array}{l}\text { Berbincang dengan } \\
\text { penayub }\end{array}$ & $\begin{array}{l}\text { Ndara-ndara } \\
\text { dan tayuban }\end{array}$ \\
\hline & & $\begin{array}{l}\text { Sabar melayani ulah } \\
\text { penayub yang kadang } \\
\text { bertindak kurang sopan }\end{array}$ & $\begin{array}{l}\text { Ndara-ndara } \\
\text { dan tayuban }\end{array}$ \\
\hline & & $\begin{array}{l}\text { Menuntun penayub } \\
\text { yang kurang hafal syair } \\
\text { tembang }\end{array}$ & Ndara-ndara \\
\hline \multirow[t]{5}{*}{4} & \multirow[t]{5}{*}{ Pengerawit } & Menabuh gamelan & \\
\hline & & Merokok & \\
\hline & & $\begin{array}{l}\text { Berbincang dengan } \\
\text { sesama pengrawit }\end{array}$ & \\
\hline & & $\begin{array}{l}\text { Melayani permintaan } \\
\text { gendhing dari penayub } \\
\text { maupun pramugari } \\
\text { Tayub }\end{array}$ & \\
\hline & & $\begin{array}{l}\text { Terkadang makan dan } \\
\text { minum di sela-sela akti- } \\
\text { vitas menabuh gamelan. }\end{array}$ & \\
\hline
\end{tabular}

Berikut salah satu contoh pementasan Langen Tayub yang dilakukan para komunitas Langen Tayub di Kabupaten Nganjuk.

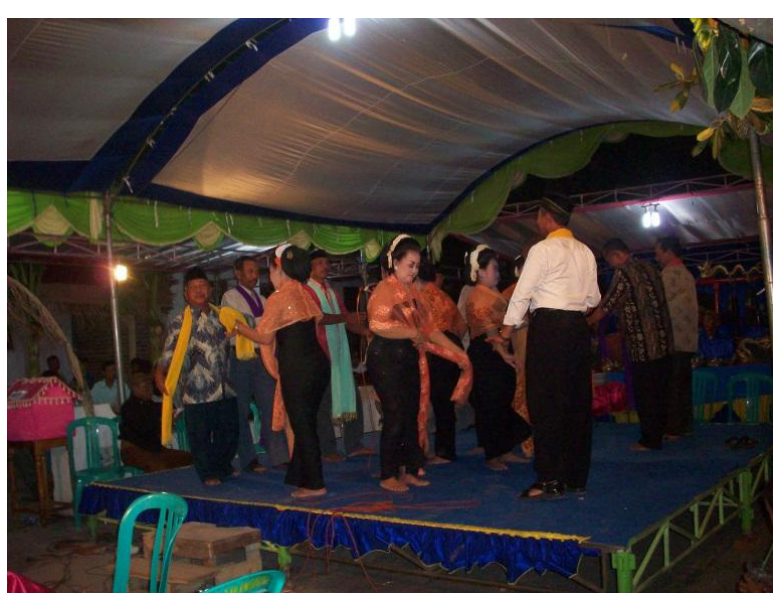

Gambar. Pertunjukan Langen Tayub dalam sebuah hajatan Perkawinan (Dok. Anik: 2009)

Berdasarkan tindakan yang dilakukan penayub diatas front stage sebagaimana tertera pada tabel 1, maka dapat diklasifikasikan tipetipe penayub yaitu sebagai berikut:

Tabel 2. Tipe-Tipe Penayub Langen Tayub

\begin{tabular}{|c|l|l|}
\hline No & Tipe & Karakteristik tindakan yang dilakukan \\
\hline 1 & Pasif & $\begin{array}{l}\text { Menari tanpa ekspresi, duduk dengan } \\
\text { penayub yang lain juga terlihat tidak ban- } \\
\text { yak bercerita atau bersenda gurau, dan lebih } \\
\text { banyak diam. }\end{array}$ \\
\cline { 2 - 3 } 2 & Genit & $\begin{array}{l}\text { Suka menggoda waranggana, menggoda } \\
\text { sesama penayub yang sedang menari diatas } \\
\text { panggung, sesekali menutup matanya den- } \\
\text { gan sampur kemudian ngliling waranggana, } \\
\text { selalu bergerak ke sana kemari. }\end{array}$ \\
\hline \multirow{2}{*}{4} & Lincah & $\begin{array}{l}\text { Sering memainkan selendang/sampur da- } \\
\text { lam menari,gerakannya lebih lincah dan } \\
\text { selaras dengan irama gendhing yang dilan- } \\
\text { tunkan. }\end{array}$ \\
\cline { 2 - 3 } & Lucu & $\begin{array}{l}\text { Gerakannya gecul/lucu, menari berpu- } \\
\text { tar-putar }\end{array}$ \\
\cline { 2 - 3 } & Ekspresif & $\begin{array}{l}\text { Gerakan sesuai irama gendhing, merasakan } \\
\text { irama yang ada kadang-kadang sampai me- } \\
\text { nutup mata,ngematke gendhing,menirukan } \\
\text { syair yang dilantunkan waranggana, keliha- } \\
\text { tan lebih sopan daripada tipe penayub yang } \\
\text { lain. }\end{array}$ \\
\hline
\end{tabular}

Berdasarkan tabel tipe-tipe penayub tersebut dapat diketahui bahwa Langen Tayub dapat menjadi media yang efektif dalam mengekspresikan / mengungkapkan berbagai 
karakter masyarakat.Suasana yang demikianlah yang membuat komunitas Langen Tayub dapat terus bertahan.Berbagai karakter individu berkumpul dan saling berinteraksi, disitulah mereka membentuk identitas komunitas.Tanpa aturan kaku ataupun ketrampilan khusus yang harus dimiliki anggota komunitas, dan tampak sederhana. Dengan kemampuan terbatas dan seadanya mereka bebas mengekpresikannya. Hal itulah yang menjadi ciri dari seni rakyat, sebagaimana pendapat SUDIKAN (1997: 13-14) yang menyatakan bahwa:"Seni pertunjukan rakyat memiliki ciri sederhana, spontan, milik komunitas dan dari komunitas, serta menyatu dengan kehidupan rakyat". Lebih lanjut dikatakan bahwa:

"Berbagai seni pertunjukan rakyat tersebut akan dikenal sebagai kesenian tradisional apabila bentuk seni tersebut bersumber dan berakar serta telah dirasakan sebagai milik sendiri oleh masyarakat lingkungannya. Pengolahannya didasarkan atas cita rasa masyarakat pendukungnya. Cita rasa di sini mempunyai pengertian yang lebih luas, termasuk : "nilai kehidupan tradisi", pandangan hidup, pendekatan filosofis, rasa etis dan estetis, serta ungkapan budaya lingkungan. Hasil kesenian tradisional biasanya diterima sebagai tradisi, pewarisan yang dilimpahkan dari generasi kepada generasi berikutnya”.

Pada proses eksternalisasi Langen Tayub di Nganjuk, tampak pada eksistensi Langen Tayub di kabupaten Nganjuk. Eksistensi itu akan terlihat dari berbagai komponen yang mendukungnya, antara lain struktur pertunjukan, urutan penyajian, gerak, iringan, tata rias, tata busana, ketentuan yang ada dalam pementasan Langen Tayub, dan eksistensi pelaku Langen Tayub itu sendiri. Komponen-komponen itu merupakan bentuk ekternalisasi yang dilakukan para pendukung kesenian Langen Tayub sejak bertahun-tahun yang lalu, hingga menjadi sebuah tradisi yang melembaga dan dijaga oleh masyarakat pendukungnya.Sebagaimana pendapat Berger yang menyatakan bahwa, upaya menjaga eksistensi itulah yang kemudian menuntut manusia menciptakan tatanan sosial. Jadi, tatanan sosial merupakan produk manusia yang berlangsung terus menerus sebagai keharusan antropologis yang berasal dari biologis manusia.

\section{SAWER DALAM LANGEN TAYUB}

Sawer merupakan hal yang tidak dapat ditinggalkan dari pementasan Langen Tayub.Sawer dalam konteks Langen Tayub merupakan tanda ucapan terima kasih penayub kepada waranggana.Dalam beberapa waktu, sawer menjadi salah satu hal yang berkonotasi negatif karena terkait dengan penyampaian sawer yang kurang sopan, yaitu dimasukkan di dada waranggana. Pihak dinas pariwisata dan kebudayaan mencoba untuk mengubah cara pemberian sawer ini dengan cara diberikan lewat berjabat tangan.

Pada Langen Tayub Nganjuk ada dua macam sawer, yaitu sawer untuk waranggana dan sawer untuk pengrawit. Di beberapa wilayah, sawer dalam seni pertunjukan bentuknya berbeda-beda. Di Nganjuk bentuk sawer, selain dari penayub untuk waranggana dan pengrawit, ada juga sawer yang dilakukan anggota keluarga pengantin khususnya yang perempuan. Bentuk sawer seperti ini terdapat di Desa Tempuran Kecamatan Ngluyu. Mereka melakukan sawer dengan cara mengelilingi waranggana dan pengantin putra yang sedang menari. Masing-masing memasukkan uang ke dalam baskom yang sudah dipersiapkan terlebih dahulu, dan jumlah uang sawer tidak ditentukan atau sukarela.Sawer yang diberikan keluarga perempuan ini merupakan ucapan terima kasih kepada seluruh crew pelaksana pementasan Langen Tayub, yaitu untuk pengrawit, pramugari Tayub dan waranggana. Di Nganjuk sawer seperti ini seperti uang wajib yang diberikan kepada modin/orang yang memimpin acara selamatan.

Menurut HastuTi (2002: 58) dalam tesisnya yang berjudul: "Sawer pada Pertunjukan Topeng dalam Konteks Hajatan di Kabupaten Indramayu Jawa Barat", menyebutkan bahwa sawer sebagai sebuah bentuk budaya yang lekat dengan pertunjukan rakyat, pada hakekatnya merupakan sesuatu yang bersifat imbal jasa. Dalam Kamus Besar Bahasa Indonesia, sawer 
mempunyai arti meminta uang kepada penonton (Moeliono, 1990: 789).

Pendapatan waranggana dari uang sawer terkadang melebihi jumlah honor yang meraka terima atas jasanya menari di pertunjukan Langen Tayub. Untuk waranggana kelas A, dengan honor sebesar Rp.700,000,00 dan sawernya apabila penayub banyak bisa mendapatkan sawer lebih dari Rp.500,000,00. Dengan jumlah penghasilan yang sebesar itu, dapat dikatakan bahwa penghasilan waranggana dengan pengrawit maupun pramugari Tayub jauh sekali perbedaannya.

Pengrawit dalam satu malam biasanya hanya mendapatkan honor antara Rp.100,000,00 sampai Rp.150,000,00. Pramugari Tayub mendapatkan honor Rp.200,000,00 - Rp.250,00,00. Untuk itu uang sawer yang ada di baki atau di baskom dikumpulkan dan dibagi untuk seluruh pengrawit. Jumlah honor pelaku Langen Tayub di Nganjuk memang tidak dapat dipatok dengan honor yang pakem, karena terkadang jumlah honor yang diterima tergantung orang yang mempunyai hajat, kalau yang mempunyai hajat kaya atau dermawan, mereka dapat menerima honor yang lebih besar. Jumlah sawer yang diberikan penayub kepada waranggana sangat bervariasi. Penayub yang loma dan mempunyai status sosial yang tinggi akan memberikan sawer dalam jumlah yang besar, misalnya Rp.50,000,00 atau bahkan Rp.100,000,00. Sementara yang lain ada yang memberi Rp, 20,000,00; Rp.10,000,00. Untuk sawer yang diberikan kepada pengrawit (yang diletakkan di baskom), minimal Rp.5,000,00.

Dalam konteks Langen Tayub pemberian sawer merupakan bentuk hubungan timbal balik yang menguntungkan, di satu sisi penayub memberikan sawer untuk memesan gendhing dan menari dengan waranggana. Waranggana sebagai orang yang menerima sawer menyediakan jasa melantunkan gendhing dan kesediaan menari dengan penayub.

\section{KEGUYUBAN DAN SOLIDARITAS DALAM LANGEN TAYUB}

Keratabasa Tayub, yang artinya ditata cik ben guyub tampak dalambeberapa bagian. Keguyuban menjadi tujuan utama pementasan Langen Tayub. Keguyuban itu dapat digolongkan dalam dua kategori:

\section{Keguyuban di luar Pementasan/Menjelang Pementasan}

Keguyuban dan solidaritas antar anggota komunitas Langen Tayub di luar arena pementasan, tampak pada konsep buwuhan yang dilakukan menjelang sebuah hajatan. Ketika anggota komunitas mempunyai hajat, solidaritas nyumbang / buwuh dalam berbagai bentuk, untuk menunjang kegiatan Langen Tayub, misalnya: sumbangan uang, membuatkan undangan, bahan makanan, bir, menyumbang terop, menyumbang waranggana, terkadang sekalian dengan pengrawitnya. Jika ada anggota yang mempunyai hajat, mereka akan menyumbang lebih dari apa yang sudah diberikan kepadanya ketika ia sendiri mempunyai hajatan.

Bentuk keguyuban yang lain adalah kehadiran dalam sebuah hajatan. Jika ada salah satu teman anggota komunitas Langen Tayub mempunyai hajat dan ada yang tidak diundang, maka teman yang lain akan mengingatkan untuk datang. Sehingga solidaritas antar teman tetap terjaga, dan keguyuban menjadi milik bersama.Dalam undangan dicantumkan turut mengundang: segenap penggemar Tayub dan juga penerima tamu tujuh orang. Hal ini menunjukkan keakraban dan solidaritas yang tinggi antar penggemar Langen Tayub. Komunitas penggemar Langen Tayub secara eksplisit dicantumkan sebagai mereka yang turut mengundang hajatan tersebut. Dengan diundang banyak orang maka penggemar yang lain akan secara "guyub" turut serta menghadiri hajatan salah satu anggotanya tersebut.

\section{Keguyuban di dalam "Kalangan" Pertunjukan}

Keguyuban dan solidaritas komunitas Langen Tayub dalam arena pertunjukan atau kadang disebut di "kalangan pertunjukan", dapat dilihat dari keguyuban dalam menanggung biaya yang harus ditanggung untuk kebutuhan bersama 
dalam satu meja. Dalam meja-meja yang sudah diatur berdasarkan asal tamu, selama pertunjukan berlangsung mereka disediakan berbagai camilan yang disebut dengan tambul.Tambul tidak disediakan orang yang mempunyai hajat, tetapi ada penjual khusus yang menyediakannya. Selain tambul mereka juga membeli minuman yang berupa bir, softdrink, dan ciu.Selesai pertunjukan makanan yang sudah disantap ditotal habis berapa, juga minuman yang sudah diminum. Setelah dijumlah habis berapa, mereka bagi sejumlah orang yang ada dalam satu meja tersebut.Jika salah satu tamu ada yang status sosialnya lebih tinggi, kadang "ngebosi"/ntraktir teman-temannya dan menanggung seluruh atau sebagian pengeluaran di meja. Jika hanya sebagian yang ditanggung, maka sisanya dibagi bersama sejumlah anggota komunitas dalam satu meja. Jika suatu saat ada anggota yang tidak mampu membayar maka akan dipinjami anggota yang lain.

Bentuk keguyuban dan solidaritas lain di dalam kalangan pertunjukan adalah jika ada anggota yang minum bir terlalu banyak hingga mengakibatkan mendem/mabuk kemudian membuat kekacauan, maka dia akan dikeluarkan dari kalangan dan diserahkan ke petugas keamanan. Ini merupakan upaya agar pementasan Langen Tayub dapat dinikmati dengan baik tanpa kekacauan/keributan serta keguyuban pertunjukan dapat terus berlangsung.Mereka sepakat untuk melangsungkan pertunjukan yang aman dan dapat dinikmati seluruh anggota komunitas.

Untuk biaya yang harus disediakan penayub dalam mengikuti pementasan Langen Tayub sangat variatif, sangat tergantung dari latar belakang sosial ekonomi dan kebutuhan dalam satu meja di Langen Tayub. Uang yang biasanya dikeluarkan antara lain untuk: buwuh kepada tuan rumah, sawer untuk waranggana dan pengrawit, biaya pembelian tambul dan minuman bir. Untuk biaya tambul ada model yang ditanggung bersama dalam satu meja/per komunitas desa/kecamatan, namun kadang-kadang ada yang memberi lebih/mentraktir, misalnya ada kepala desa yang memberi Rp.200,000,00 untuk kebutuhan tambul di mejanya, jika ada kekurangan maka sisa kekurangan baru dibagi bersama.

\section{PENUTUP}

Konstruksi Langen Tayub di Nganjuk, tampak pada eksistensi Langen Tayub di kabupaten Nganjuk. Eksistensi itu akan terlihat dari berbagai komponen yang mendukungnya, antara lain struktur pertunjukan, urutan penyajian, gerak, iringan, tata rias, tata busana, ketentuan yang ada dalam pementasan Langen Tayub, dan eksistensi pelaku Langen Tayub itu sendiri. Komponen-komponen itu merupakan bentuk ekternalisasi yang dilakukan para pendukung kesenian Langen Tayub sejak bertahun-tahun yang lalu, hingga menjadi sebuah tradisi yang melembaga dan dijaga oleh masyarakat pendukungnya.Sebagaimana pendapat Berger yang menyatakan bahwa, upaya menjaga eksistensi itulah yang kemudian menuntut manusia menciptakan tatanan sosial.

\section{DAFTAR PUSTAKA}

1994 Langit Suci, Agama sebagai Realitas Sosial, (diterjemahkan dari buku asli Sacred Canopy oleh Hartono). Jakarta:LP3ES.

Berger, Peter dan Thomas Luckmann.

1990 Tafsir Sosial atas Kenyataan; Risalab tentang Sosiologi Pengetabuan (diterjemahkan dari buku asli The Social Construction of Reality oleh Hasan Basri) Jakarta:LP3ES.

Berger, Peter L

1967 The Social Construction of Reality: A Treatise in the Sociology of Knowledge. New York: Anchor Books Doubleday \& Company.

Berger, Peter L

1991 Kabar Angin dari Langit: Makna Teologi da lam masyarakat Modern (diterjemahkan 
dari buku asli A Rumor of Angel:

Modern Society and the Rediscovery

of the Supernatural oleh J.B. Sudarman

to. Jakarta: LP3ES.

HASTUTI, SRI.

2002 Sawer Pada Pertunjukan Topeng Dalam Kon teks Hajatan Di Kabupaten Indramayu Jawa Barat. Tesis Program S2 Pascasarjana Universitas Gadjah Mada, Yogyakarta, tidak dipublikasikan.

Poloma, MARGARET M.

2000 Sosiologi Kontemporer. Jakarta:PT.Raja Grafindo Persada.

Sudikan, SETYA YuWANA.

1997 "Tantangan Seni Pertunjukan Rakyat (Tradisional) dalam Menghadapi Era Teknologi Komunikasi” (Seniman sebagai Agen Perubahan Sosio-Budaya di Pedesaan) dalam Prasasti, No.26 Tahun VII April. hal.13-23.

Susilo, RaCHMAD K. DwI.

200820 Tokob Sosiologi Modern. Yogyakarta: Ar.Ruzz Media. 